\title{
DILITHIUM SEQUESTRENE AS AN ANTICOAGULANT
}

BY

\author{
L. S. SACKER, ${ }^{*}$ K. E. SAUNDERS, $\dagger$ BERYL PAGE, AND MARGARET \\ GOODFELLOW \\ From the Departments of Pathology, Dulwich and Lewisham Hospitals, London
}

(RECEIVED FOR PUBLICATION SEPTEMBER 20, 1958)

The variety of different anticoagulants used for blood samples has increased, but there is still need for a suitable anticoagulant for the routine estimation of sodium and potassium by flame photometry. So far the only satisfactory substance for this purpose has been the expensive calcium heparin (King and Wootton, 1956).

Disodium sequestrene (Proescher, 1951 ; Hadley and Larson, 1953) and dipotassium sequestrene (Hadley and Weiss, 1955) are the most valuable of the recently introduced anticoagulants for routine haematological procedures because they preserve the morphology of leucocytes for short periods better than the ammonium and potassium oxalate mixture or heparin, and they prevent platelets clumping and preserve them. The disodium sequestrene is less satisfactory than the dipotassium salt because of its lower solubility in blood.

Dilithium sequestrene was prepared and its properties as an anticoagulant were investigated. It was found to have the properties of dipotassium sequestrene in routine haematological work but could also be used in many biochemical procedures, including flame photometry. This salt had previously been investigated (Hadley and Weiss, 1955) and found to be unsatisfactory because of its low solubility.

\section{Preparation}

Dilithium sequestrene can be prepared from sequestric acid by reaction with the theoretical amounts of either lithium carbonate or lithium hydroxide.

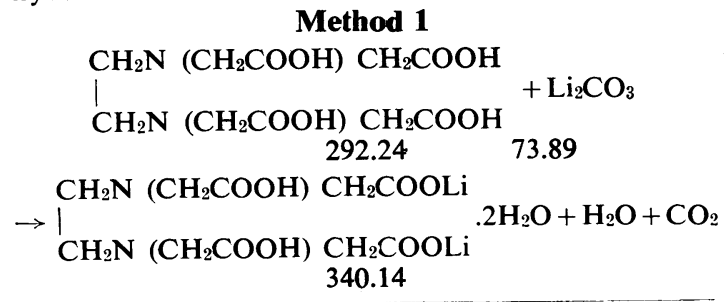

*Present address: Kingston Hospital, Hull.

tPresent address: Brook Hospital, Woolwich, London, S.E.18.
Ethylene diamine tetra-acetic acid (E.D.T.A.), 29.2 g., and $7.4 \mathrm{~g}$. of lithium carbonate were intimately mixed. Then $200 \mathrm{ml}$. of water was added and solution took place with vigorous evolution of carbon dioxide.

\section{Method 2}

E.D.T.A., $29.2 \mathrm{~g}$., was dissolved in $200 \mathrm{ml}$. of normal lithium hydroxide solution (41.96 g. $\mathrm{LiOH} . \mathrm{H}_{2} \mathrm{O}$ per litre).

In both cases the resulting solution contained the dilithium salt.

Dilithium sequestrene was obtained from these solutions after filtration to remove a small quantity of amorphous debris, by precipitation on the addition of an equal volume of absolute methyl alcohol and cooling. Dilithium sequestrene separated out as a fine white crystalline substance which was recovered by filtration on a buchner funnel and washed four times with $10 \mathrm{ml}$. of absolute methyl alcohol. The salt was dried at atmospheric pressure over anhydrous calcium chloride to a constant weight.

The usual yield by either of these methods was 29 g., namely, $85 \%$ of the theoretical yield.

\section{Physical Properties}

The substance produced by either method was identical. It was a white micro-crystalline solid which had a solubility in water of $16 \mathrm{~g}$. per 100 $\mathrm{ml}$. at $18^{\circ} \mathrm{C}$. and was freely soluble in $10 \% \mathrm{v} / \mathrm{v}$ methyl alcohol in water but insoluble in absolute methyl alcohol. The melting point was $300^{\circ} \mathrm{C}$. with decomposition. The theoretical lithium content of the dilithium salt is $4.08 \%$ and the estimated lithium content was $4.16 \%$ using the EEL flame photometer. This confirms that the dilithium salt has been produced.

Carbon and hydrogen estimations were performed on the dilithium sequestrene and the results obtained were hydrogen content $5.4 \%$ and carbon content $37.08 \%$. The theoretical values for dilithium sequestrene with two molecules of water of crystallization is hydrogen $5.33 \%$ and carbon $35.3 \%$. 


\section{Distribution as an Anticoagulant}

Distribution of dilithium sequestrene from aqueous solution. was unsatisfactory as the deposit was difficult to dissolve in blood.

The most efficient method of distributing dilithium sequestrene was by placing the appropriate amount of a solution containing $2.1 \mathrm{~g}$. per $100 \mathrm{ml}$. in $10 \% \mathrm{v} / \mathrm{v}$ methyl alcohol in water into each universal container. These containers were placed in a hot air oven at $160^{\circ} \mathrm{C}$. for 30 minutes. This procedure did not affect the anticoagulant properties of the salt or in any way lower its solubility in blood or cause its decomposition. All traces of methyl alcohol were also removed.

The optimal amount of dilithium sequestrene for routine haematological and chemical estimations was found to be $0.2 \mathrm{ml}$. of this solution for $5 \mathrm{ml}$. of blood, i.e., $0.84 \mathrm{mg}$. per $\mathrm{ml}$. The minimum amount to prevent coagulation is $0.52 \mathrm{mg}$. per $\mathrm{ml}$.

The tolerance for haematological procedures, which ensures retention of good cell morphology, is between $1.05 \mathrm{mg}$. and $0.66 \mathrm{mg}$. per ml. of blood.

The tolerance for blood urea and electrolytes, except plasma chloride, is between the minimum amount necessary to prevent coagulation, i.e., 0.52 $\mathrm{mg}$., and $4.2 \mathrm{mg}$. per $\mathrm{ml}$. of blood.

For chlorides between 0.52 and $1.4 \mathrm{mg}$. per $\mathrm{ml}$. is satisfactory.

Dipotassium and disodium sequestrene have been distributed into universal containers using the method previously described. The solubility of these salts in blood was as good as the solubility of dilithium salt under similar conditions.

Comparative chemical estimations were made on samples of the same blood taken into dilithium sequestrene and calcium heparin.

Comparative haematological investigations were made on samples of the same blood taken into dilithium sequestrene, dipotassium sequestrene, and the ammonium and potassium oxalate mixture.

\section{Results}

Chemical Investigations. - The wavelength of the emission spectrum for lithium is $6708 \AA$, for sodium $5890 \AA$ and $5896 \AA$, and for potassium $7655 \AA$. Using the EEL flame photometer with a coal gas/air flame no interference was detected due to lithium on the intensity of the sodium or potassium emission spectra, even when using 10 times the amount of lithium sequestrene normally present.

Sodium and potassium were estimated, using the flame photometer, on plasma from samples of blood anticoagulated with either calcium heparin or dilithium sequestrene. Plasma chloride was estimated by the method of Schales and Schales (1941).

Blood urea was estimated by the method of Archer and Robb (1925) and plasma bicarbonate in the volumetric Van Slyke apparatus.

The electrolyte results obtained from 100 comparable samples of plasma are tabulated in Table I.

TABLE I

COMPARABLE ELECTROLYTE RESULTS

\begin{tabular}{|c|c|c|c|c|c|}
\hline & & \multicolumn{4}{|c|}{ Range of Variation (mEq. per Litre) } \\
\hline & & \pm 2 & \pm 4 & $> \pm 4$ & $\begin{array}{l}\text { Mean } \\
\text { Error }\end{array}$ \\
\hline \multirow[t]{3}{*}{$\begin{array}{l}\text { Sodium } \\
\text { Chloride } \ldots \\
\text { Bicarbonate }\end{array}$} & $\begin{array}{l}\cdots \\
\cdots \\
\cdots\end{array}$ & $\begin{array}{l}75 \\
84 \\
99\end{array}$ & $\begin{array}{r}25 \\
15 \\
1\end{array}$ & $\begin{array}{l}0 \\
1 \\
0\end{array}$ & $\begin{array}{l}+0.04 \\
+1 \\
+0.08\end{array}$ \\
\hline & & \multicolumn{4}{|c|}{ mEq. per litre } \\
\hline & & $\pm \mathbf{0 . 2}$ & \pm 0.4 & $> \pm 0.4$ & \\
\hline Potassium .. & $\cdots$ & 95 & 4 & 1 & -0.015 \\
\hline
\end{tabular}

Of the 100 comparative urea estimations, 99 were within $10 \%$ of the calcium heparin standard and one only was outside this range. The figures in this case were $43 \mathrm{mg}$. per $100 \mathrm{ml}$. for the calcium heparin and $38 \mathrm{mg}$. for the sequestrene estimation.

Sequestrene plasma was also found to be equally effective for the estimations of bilirubin, cholesterol, and the phosphatases.

Blood sugar estimations performed by either the Hagedorn and Jensen or Folin and Wu methods were unsatisfactory when compared with blood containing fluoride, as there was a rapid loss of reducing substance. It was, however, noted that the loss in the first one and a half hours after collection was about $5 \%$, so that estimations performed on blood within this time or when fluoride was added within this time were satisfactory.

Haematological Investigations.-In the investigation of dilithium sequestrene as an anticoagulant for haematological investigations a comparison was made between samples of the same blood taken into the ammonium and potassium oxalate mixture, which were estimated after contact with the anticoagulant for one hour, and dipotassium sequestrene and dilithium sequestrene, which were estimated after one and four hours' contact with the anticoagulant.

On each sample of blood taken in the ammonium and potassium oxalate mixture after one hour and each sample in dipotassium or 
dilithium sequestrene after one and four hours the following investigations were performed:

(1) Haemoglobin using the oxyhaemoglobin method reading in a photo-electric colorimeter using an Ilford 625 filter, (2) blood sedimentation rate (Wintrobe method); (3) packed cell volume using an M.S.E. haematocrit centrifuge governed to 3,000 r.p.m. for 30 minutes ; (4) platelet count using direct counting in blood diluted either 1 in 20 in Barr's fluid or 1 in 100 in formol citrate (Dacie, 1956) ; (5) total white cell count ; (6) blood films had differential white cell counts performed and were also examined for red cell morphology, platelet clumping and morphology, and the effect of the anticoagulants on leucocyte morphology.

Increased red cell destruction after contact with each of the three anticoagulants used was not found, as shown by spectroscopic examination of the supernatant plasma, plasma haemoglobin estimations, or the potassium level of separated plasma.

The results obtained by these methods on 50 different samples of blood are summarized.

(1) Haemoglobin Levels.-The maximum difference between all the five haemoglobin estimations on one samp'e of blood was less than $10 \%$ in all specimens and less than $5 \%$ in $60 \%$ of the specimens.

(2) The Sedimentation Rate.-A Wintrobe technique blood sedimentation rate was performed on each sample of blood after one and four hours' contact with each of the three anticoagulants used.

Seventy-six per cent. of these groups of samples gave readings within $2 \%$ of each other when all three anticoagulants were compared at one and at four hours' contact.

The remaining $24 \%$ gave identical readings at one hour but showed marked and erratic increase of the sedimentation rate after four hours' contact with the anticoagulant.

(3) Packed Cell Volume.-Generally there was less than $1 \%$ difference on any sample of the same specimen, but in eight specimens $(16 \%)$ a constant reduction of $1 \%$ was noted in those samples which had been in contact with the dipotassium or dilithium sequestrene, or ammonium and potassium oxalate anticoagulant for four hours when compared with a contact time of one hour. This is suggestive of a minor degree of red cell shrinkage due to the anticoagulant.

(4) Platelet Count.-Platelet counts on the blood taken in the ammonium and potassium oxalate mixture were unsatisfactory as in all samples platelets had clumped.
Platelet counts on sequestrene blood were satisfactory. All duplicate platelet counts varied within a range of $\pm 10 \%$, which is satisfactory.

It was noted occasionally that the platelets clumped in dilithium sequestrene if the anticoagulant had not been heated correctly at $160^{\circ} \mathrm{C}$. for 30 minutes.

(5) White Cell Count.-The maximum variation noted in wet counts was well within $20 \%$ limits (Dacie, 1956).

(6) Blood Films.-(a) No significant difference in the differential white cell counts was noted between the ammonium and potassium oxalate anticoagulant after one hour and dipotassium and dilithium sequestrene after one and four hours' contact time.

(b) Red cell morphology appeared to be unaffected by the anticoagulants used.

(c) Platelets were clumped, usually into small clumps with a few free platelets, by the ammonium and potassium oxalate anticoagulant after one hour's contact.

Platelets remained free, evenly distributed throughout the films and of good morphology with either of the sequestrene anticoagulants.

(d) Leucocyte Morphology.-Nearly all films from blood in ammonium and potassium oxalate anticoagulant showed changes in the leucocytes due to anticoagulants. Most films showed between $4 \%$ and $10 \%$ of white cells affected by this anticoagulant after one hour's contact.

Most films made from either sequestrene anticoagulant after one hour's contact failed to show any loss of morphological characteristics.

After four hours' contact with either of the sequestrene anticoagulants $60 \%$ of films showed no loss of morphological characteristics in the white cells, $34 \%$ showed between $1 \%$ and $2 \%$ of white cells affected, and $6 \%$ showed from $3 \%$ to $5 \%$ of white cells affected.

Dilithium sequestrene is not satisfactory for the estimation of prothrombin time.

\section{Conclusion}

Dilithium sequestrene is as good an anticoagulant for standard haematological investigations as dipotassium sequestrene.

Dilithium sequestrene is a good anticoagulant for many of those chemical investigations normally performed on serum, such as sodium, potassium, chloride, bicarbonate, urea, phosphatases, cholesterol, and bilirubin. This is particularly important with the electrolytes, as it 
enables rapid separation of the plasma, more accurate results due to this rapid separation, and less delay when these investigations are performed as emergency procedures.

Dilithium sequestrene is easy to produce and distribute and the cost is low. The reagents to make $30 \mathrm{~g}$. of this salt cost approximately $2 \mathrm{~s}$. $6 \mathrm{~d}$.

\section{Summary}

The preparation and distribution of dilithium sequestrene, which may be used as a universal laboratory anticoagulant, are described.
This anticoagulant and the more usual laboratory anticoagulants for haematological and biochemical procedures are compared.

We wish to thank Dr. E. N. Allott and Dr. J. C. Thompson for their advice and co-operation during this investigation, and Miss P. A. Wyatt and Mr. A. P. Reynolds for their technical assistance.

\section{REFERENCES} Archer, H. E., and Robb, G. D. (1925). Quart. J. Med., 18, 274.
Dacie, J. V. (1956). Practical Haematology, 2nd ed. Churchill,

London.
Hadley, G. G., and Larson, N. L. (1953). Amer. J. clin. Path., 23, 613. and Weiss, S. P. (1955). Ibid., 25, 1090.

King, E. J., and Wootton, I. D. P. (1956). Micro-Analysis in Medical Biochemistry, 3rd ed. Churchill, London.

Proescher, F. (1951). Proc. Soc. exp. Biol. (N.Y.), 76, 619.

Schales, O., and Schales, S. S. (1941). J. biol. Chem., 140, 879. 